\title{
CREATION OF VIABLE PULMONARY ARTERY AUTOGRAFTS THROUGH TISSUE ENGINEERING
}

Toshiharu Shinoka, MD

Dominique Shum-Tim, MD

Peter X. Ma, $\mathrm{PhD}^{\mathrm{b}}$

Ronn E. Tanel, $\mathrm{MD}^{\mathrm{c}}$

Noritaka Isogai, $\mathrm{MD}^{\mathrm{d}}$

Robert Langer, $\mathrm{PhD}^{\mathrm{b}}$

Joseph P. Vacanti, MD ${ }^{\mathrm{d}}$

John E. Mayer, Jr., MD ${ }^{\mathrm{a}}$
Background: "Repair" of many congenital cardiac defects requires the use of conduits to establish right ventricle to pulmonary artery continuity. At present, available homografts or prosthetic conduits lack growth potential and can become obstructed by tissue ingrowth or calcification leading to the need for multiple conduit replacements. Tissue engineering is an approach by which cells are grown in vitro onto biodegradable polymers to construct "tissues" for implantation. A tissue engineering approach has recently been used to construct living cardiac valve leaflets from autologous cells in our laboratory. This study assesses the feasibility of a tissue engineering approach to constructing tissue-engineered "living" pulmonary artery conduits. Materials and methods: Ovine artery (group $\mathrm{A}, n=4$ ) or vein (group $\mathrm{V}, n=3$ ) segments were harvested, separated into individual cells, expanded in tissue culture, and seeded onto synthetic biodegradable (polyglactin/polyglycolic acid) tubular scaffolds $(20 \mathrm{~mm}$ long $\times 15 \mathrm{~mm}$ diameter). After 7 days of in vitro culture, the autologous cell/polymer vascular constructs were used to replace a $2 \mathrm{~cm}$ segment of pulmonary artery in lambs (age $68.4 \pm 15.5$ days, weight $18.7 \pm 2.0 \mathrm{~kg}$ ). One other control animal received an acellular polymer tube sealed with fibrin glue without autologous cells. Animals were sacrificed at intervals of 11 to 24 weeks (mean follow-up $130.3 \pm 30.8$ days, mean weight $38.9 \pm 13.0 \mathrm{~kg}$ ) after echocardiographic and angiographic studies. Explanted tissue-engineered conduits were assayed for collagen (4-hydroxyproline) and calcium content, and a tissue deoxyribonucleic acid assay (bis-benzimide dye) was used to estimate number of cell nuclei as an index of tissue maturity. Results: The acellular control graft developed progressive obstruction and thrombosis. All seven tissue-engineered grafts were patent and demonstrated a nonaneurysmal increase in diameter (group $A=18.3 \pm 1.3 \mathrm{~mm}=95.3 \%$ of native pulmonary artery; group $V=17.1 \pm 1.2 \mathrm{~mm}=86.8 \%$ of native pulmonary artery). Histologically, none of the biodegradable polymer scaffold remained in any tissue-engineered graft by 11 weeks. Collagen content in tissue-engineered grafts was $\mathbf{7 3 . 9 \%} \pm \mathbf{8 . 0 \%}$ of adjacent native pulmonary artery. Histologically, elastic fibers were present in the media layer of tissue-engineered vessel wall and endothelial specific factor VIII was identified on the luminal surface. Deoxyribonucleic acid assay showed a progressive decrease in numbers of cell nuclei over 11 and 24 weeks, suggesting an ongoing tissue remodeling. Calcium content of tissue-
From the Departments of Cardiovascular Surgery, ${ }^{\text {a }}$ Surgery, ${ }^{\mathrm{d}}$ and Cardiology, ${ }^{\mathrm{c}}$ Children's Hospital, Boston, Mass., and the Department of Chemical Engineering, Massachusetts Institute of Technology, ${ }^{\mathrm{b}}$ Cambridge, Mass.

This work was supported by generous grants from the Department of Cardiac Surgery, Children's Hospital, Boston, Advanced Tissue Sciences, Inc., La Jolla, the Thomas Anthony Pappas Charitable Foundation, Inc., Boston and the Department of Surgery, Children's Hospital, Boston.
Read at the Seventy-seventh Annual Meeting of The American Association for Thoracic Surgery, Washington, D.C., May 4-7, 1997.

Received for publication May 6, 1997; accepted for publication Sept. 18, 1997.

Address for reprints: John E. Mayer, Jr., MD, Department of Cardiovascular Surgery, Boston Children's Hospital, 300 Longwood Ave., Boston, MA 02115.

J Thorac Cardiovasc Surg 1998;115:536-46

Copyright (C) 1998 by Mosby, Inc.

0022-5223/98 $\$ 5.00+0 \quad \mathbf{1 2 / 6 / 8 6 3 4 2}$ 
engineered grafts was elevated (group $A=7.95 \pm 5.09$; group $V=13.2 \pm$ 5.48; native pulmonary artery $=1.2 \pm 0.8 \mathrm{mg} / \mathrm{gm}$ dry weight), but no macroscopic calcification was found. Conclusions: Living vascular grafts engineered from autologous cells and biodegradable polymers functioned well in the pulmonary circulation as a pulmonary artery replacement. They demonstrated an increase in diameter suggesting growth and development of endothelial lining and extracellular matrix, including collagen and elastic fibers. This tissue-engineering approach may ultimately allow the development of viable autologous vascular grafts for clinical use. (J Thorac Cardiovasc Surg 1998;115:536-46)

$\mathrm{C}^{\mathrm{h}}$ hildren who undergo ventricle-pulmonary artery (PA) connections with either prosthetic or homograft extracardiac conduits require multiple reoperations because of conduit failure. ${ }^{1}$ Bioprosthetic conduits and allogenic graft replacements have certain disadvantages that greatly limit their long-term benefits. These conduits are foreign materials that lack the ability to grow, repair, or remodel. More important, they are potentially thrombogenic and susceptible to infection throughout their life span. These inherent problems have significantly limited their durability, especially in the pediatric age group. The search for an ideal conduit is still ongoing. In an attempt to overcome the shortcomings of currently available conduits, we tested the feasibility of constructing tissue-engineered conduits in lambs with autologous arterial and venous wall cells containing myofibroblasts and endothelial cells seeded in vitro onto a synthetic polyglycolic acid (PGA) fiber matrix. We have previously reported the feasibility of using the TE approach to construct heart valve leaflets. ${ }^{2,3}$ This study was carried out to evaluate whether autologous tissue-engineered conduits could maintain the pulmonary circulation in a growing lamb model.

\section{Methods}

The techniques of cell isolation, culture, cell sorting, polymer characteristics, and cell seeding were previously described in detail. ${ }^{4}$ Briefly, 2 to $3 \mathrm{~cm}$ sections of carotid artery were harvested from 20-day-old lambs (group A, $n=4$ ), minced, and cultured in Dulbecco's Modified Eagle Medium (Gibco BRL-Life Technologies, Grand Island, N.Y.) supplemented with $10 \%$ fetal bovine serum (Sigma Chemicals, St. Louis, Mo.) and 1\% guinea pig serum $(29.2 \mathrm{mg} / \mathrm{ml} \mathrm{l-glutamine,} 10,000 \mathrm{units} / \mathrm{ml}$ penicillin $\mathrm{G}$ sodium, and 10,000 $1 \times \mathrm{gm} / \mathrm{ml}$ streptomycin (Gibco) media. In the other three animals (group V), 2 to $3 \mathrm{~cm}$ sections of jugular vein in lambs were harvested and cultured in the same manner. The media was changed every 7 days, and in vitro cell growth was assessed periodically. The explanted tissue culture was placed in a humidified incubator maintained at $37^{\circ} \mathrm{C}$ with $5 \%$ carbon dioxide for 6 to 9 weeks. Cell growth from the explants was observed after several days to form mixed cell populations of endothelial cells and fibroblasts. The cultured cells were then labeled with an acetylated low-density lipoprotein marker (Biomedical Technologies Inc., Stoughton, Mass.), which is selectively taken up by endothelial cells through the scavenger pathway. After a 24hour incubation period, the cells were sorted into lowdensity lipoprotein-positive endothelial cells, and lowdensity lipoprotein-negative fibroblasts and smooth muscle cells with a fluorescent activated cell sorter. Endothelial cells were found in $2 \%$ to $3 \%$ of mixed cell culture in both groups after 2 weeks in vitro culture. The tubular tissue scaffold ( $20 \mathrm{~mm}$ long $\times 15 \mathrm{~mm}$ in diameter) was composed of a polyglactin woven mesh (Ethicon, Inc., Somerville, N.J.) sealed with nonwoven PGA mesh (Albany International Research Co., Mansfield, Mass.) inside the lumen (Fig. 1). The mesh matrix was greater than $95 \%$ porous before seeding. The scaffold was designed so that it would be biodegraded over a 6 - to 8 -week period. ${ }^{5}$ In each group, 10 million mixed cultured cells were seeded onto the polymer. Culture media was changed on a daily basis. After 7 days, cells became confluent on the polymer in both groups.

PA replacement. Autologous tissue-engineered conduits were implanted into the same lambs from which the cells had been previously harvested (average age $68.4 \pm$ 15.5 days, body weight $18.7 \pm 2.0 \mathrm{~kg}$ ). One other animal received an acellular polymer tube sealed with pasteurized fibrin glue (Bolheal, The ChemoSero-Therapeutic Research Institute, Japan) consisting of fibrinogen (80 mg/ $\mathrm{ml})$, thrombin (250 units $/ \mathrm{ml})$, plasmin inhibitor aprotinin $(1000 \mathrm{KIE} / \mathrm{ml})$, calcium chloride $(5.9 \mathrm{mg} / \mathrm{ml})$, and fibrinstabilizing factor VIII (75 units/ml). This prevented blood leaking through the acellular polymer tube.

Anesthesia was induced with $30 \mathrm{mg} / \mathrm{kg}$ of intramuscular ketamine and maintained with continuous infusion of 0.2 $\mathrm{mg} / \mathrm{kg}$ per minute of propofol. The chest was exposed through a left thoracotomy at the third intercostal space. Normothermic femoral arterial and right atrial cardiopulmonary bypass was established. With the heart beating, the PA was transected and a $2 \mathrm{~cm}$ section of main PA was resected and replaced with either a tissue-engineered conduit or a plain polymer conduit with 5-0 monofilament sutures. All animals received humane care in compliance with the "Guide for the Care and Use of Laboratory 

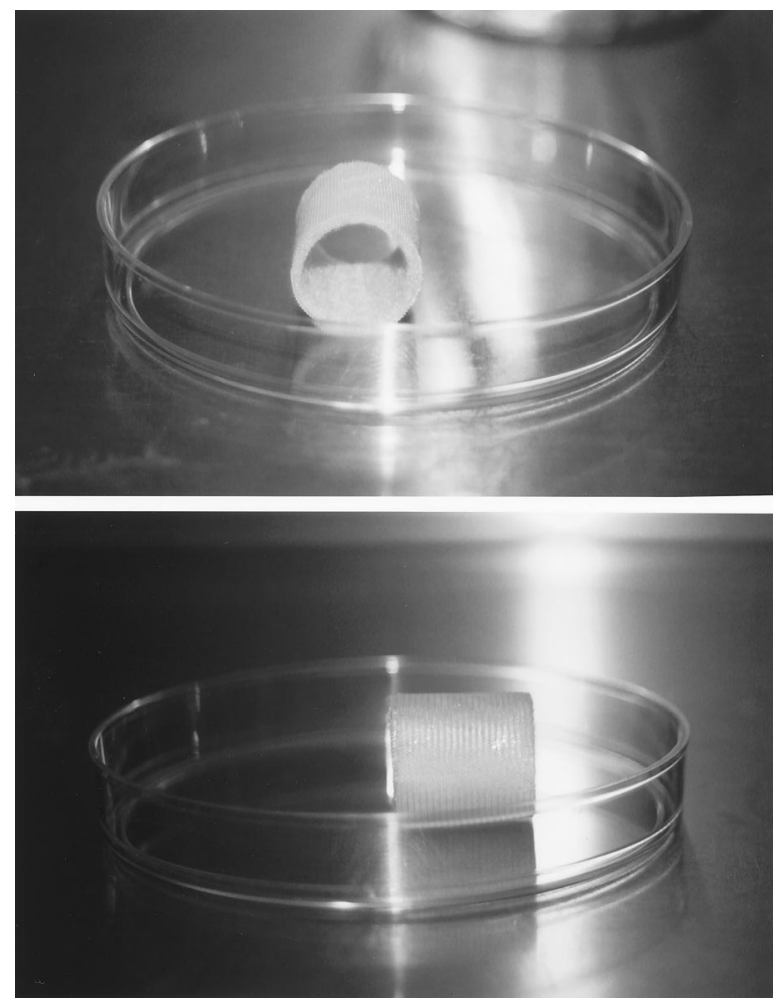

Fig. 1. Polymer scaffold (top, frontal view; bottom, lateral view) $15 \mathrm{~mm}$ in diameter and $20 \mathrm{~mm}$ long.

Animals" published by the National Institutes of Health (NIH Publication No. 85-23, revised 1985).

Evaluation of tissue-engineered conduits. After implantation, Doppler echocardiography was used periodically to evaluate conduit patency and growth potential. All animals underwent angiography immediately before they were killed. The diameter of tissue-engineered conduit was measured angiographically and compared with that of adjacent native main PA and expressed as percentage of native PA.

Animals were killed and main PAs were explanted at 75 to 169 days after implantation (average interval after implantation $125.4 \pm 20.8$ days, body weight $38.6 \pm 13.9$ $\mathrm{kg}$ ). After the animals were killed, a portion of the specimen was fixed with $10 \%$ formalin for histologic examination with hematoxylin and eosin or Miller's elastic stain. The other portion was immersed in $0.9 \%$ saline solution and immediately processed for collagen, calcium, and deoxyribonucleic acid (DNA) assays. A 4-hydroxyproline assay ${ }^{6}$ was used to measure the collagen content in the tissue-engineered conduits. DNA assay ${ }^{7}$ was used to determine the cell density in the tissue. The collagen and DNA content of these constructs were compared with the native PA of the same animal and expressed as a percentage of the native artery. The ortho-cresolphthalein complexon (OCPC) method was used for calcium measurement. ${ }^{8}$ Additional sections of the conduits were also stained for factor VIII with immunohistochemical tech- nique with a monoclonal anti-factor VIII antibody (BioGenex, San Ramon, Calif.). ${ }^{9}$

\section{Results}

Echocardiographic and angiographic findings. Two weeks after implantation, echocardiography showed patent conduits in all group $\mathrm{A}$ and $\mathrm{V}$ animals. Thrombus formation was identified in the control animal causing PA stenosis. The echo density of the conduit was initially higher than native PA partly attributed to the presence of polymer. (Fig. 2, $a$ and $c$ ). After 10 to 12 weeks, tissueengineered conduits showed no evidence of thrombus formation or calcification in either group $\mathrm{A}$ or $\mathrm{V}$. In addition, the high-density material in the conduit wall had disappeared (Fig. 2, $b$ and $d$ ). On angiography, all conduits showed an increase in diameter compared with that at the time of implantation (Figs. 3 and 4). However, the percentage diameter remained $95 \% \pm 1.7 \%$ in group $\mathrm{A}$ and $86.8 \% \pm 2.9 \%$ in group $\mathrm{V}$ compared with the native PA, respectively (Fig. 5, $a$ ).

Macroscopic findings. The gross appearance of the tissue-engineered conduits in both group A and $\mathrm{V}$ resembled the native $\mathrm{PA}$, although they were somewhat thinner (Fig. 6). The control animal was killed 2 weeks after implantation because of severe dyspnea and pulmonary stenosis. Progressive thrombus formation and contraction of the polymer wall was found (Fig. 6,e).

Histologic examination. The predominance of polymer was confirmed histologically in control animals killed 2 weeks after implantation. The specimens from the group $\mathrm{A}$ or $\mathrm{V}$ showed almost complete disappearance of PGA polymer, and the tissue-engineered conduit resembled the native pulmonary vascular cellular architecture. Millers elastic stain showed evidence of elastic and collagen fiber in the engineered artery wall (Fig. 7).

Immunohistochemical staining. Factor VIIIstained endothelial cells were found lining the luminal surface of the tissue-engineered conduit (Fig. 8) in six of six conduits (three in group A and three in group V).

Biochemical examination. The 4-hydroxyproline assay demonstrated that the tissue-engineered conduit contained about $70 \%$ collagen content compared with native PA (Fig. 5, b).

Calcium assay. In tissue-engineered conduits, calcium content was elevated compared with native PA (group $\mathrm{A}=7.95 \pm 5.09$, group $\mathrm{V}=13.2 \pm 5.48$, 




Fig. 2. Echocardiography. a, Group A; 2 weeks after implantation TE conduit still contained high-density material (polymer). b, Group A: 10 weeks after implantation. TE conduit showed no evidence of stenosis or dilatation. c, Control; 2 weeks after implantation. Massive thrombus in the conduit. d, Group V; 16 weeks after implantation. TE conduit showed no evidence of stenosis or dilatation or calcification.

native $\mathrm{PA}=1.2 \pm 0.8 \mathrm{mg} / \mathrm{gm}$ dry weight), but no macroscopic calcification was found (Fig. 5, c).

DNA assay. DNA content (cell nuclei density per gram dry tissue) in the tissue-engineered conduit was higher than native PA tissue when the animal was killed (group A, $180.0 \% \pm 50.7 \%$; group V, $148.3 \% \pm 22.3 \%$ ) (Fig. 5, $d$ ).

\section{Discussion}

The search for an ideal vascular conduit for use in children continues because all the current synthetic or bioprosthetic grafts used clinically are far from ideal vascular replacements. None have growth potential; therefore durability is limited for growing children.

All synthetic grafts are thrombogenic to some extent. Tightly woven grafts have been used in the past because their low porosity was preferable in patients given heparin. However, these grafts have the disadvantage of poor neointima formation and tissue ingrowth, which promotes calcification. In- evitably, progressive increases in pressure gradients develop over time across these conduits, and, by 10 years all conduits required replacement when used in the pulmonary circulation in our institute. $^{1,10}$

Homografts currently seem to be the best conduits that fulfill the physical and handling requirements for applications in pediatric patients with defects requiring right ventricle to PA connection. These grafts have been reported to be superior to other synthetic conduits, but in other reports they do not seem to offer much advantage over prosthetic grafts. ${ }^{1,11}$ At present, homograft conduits are cryopreserved and stored in liquid nitrogen until used. Cryopreservation has been suggested to preserve fibroblast viability, ${ }^{12,13}$ which might theoretically result in growth potential and make them less thrombogenic. Nevertheless, the presence of viable allograft components may enhance immune rejection, leading to calcification and subsequent failure. In addition, homograft donor scarcity remains a 

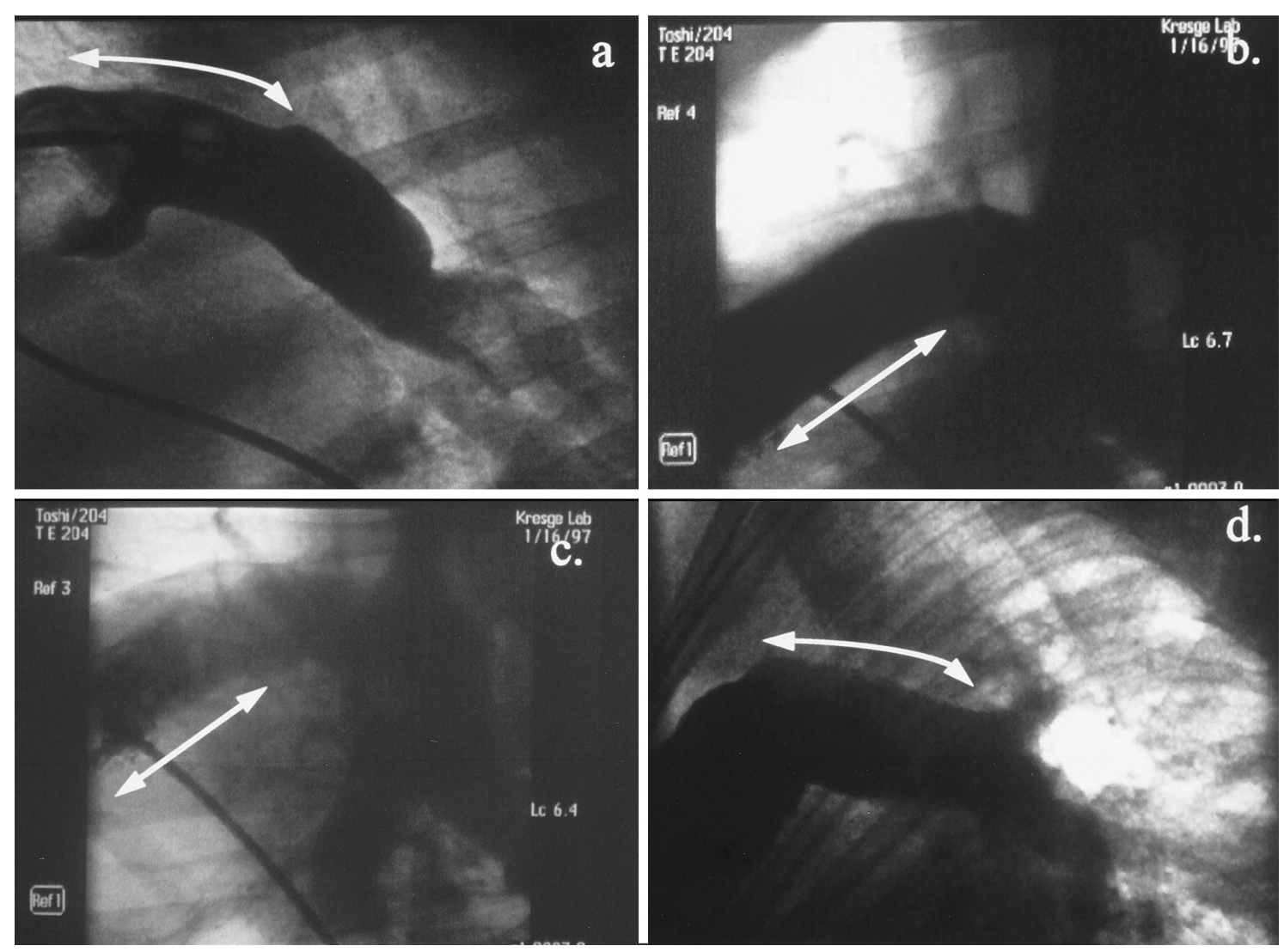

Fig. 3. Pulmonary artery angiography. Arrows indicate tissue-engineered conduit. a and b, Group A. c and d, Group V.

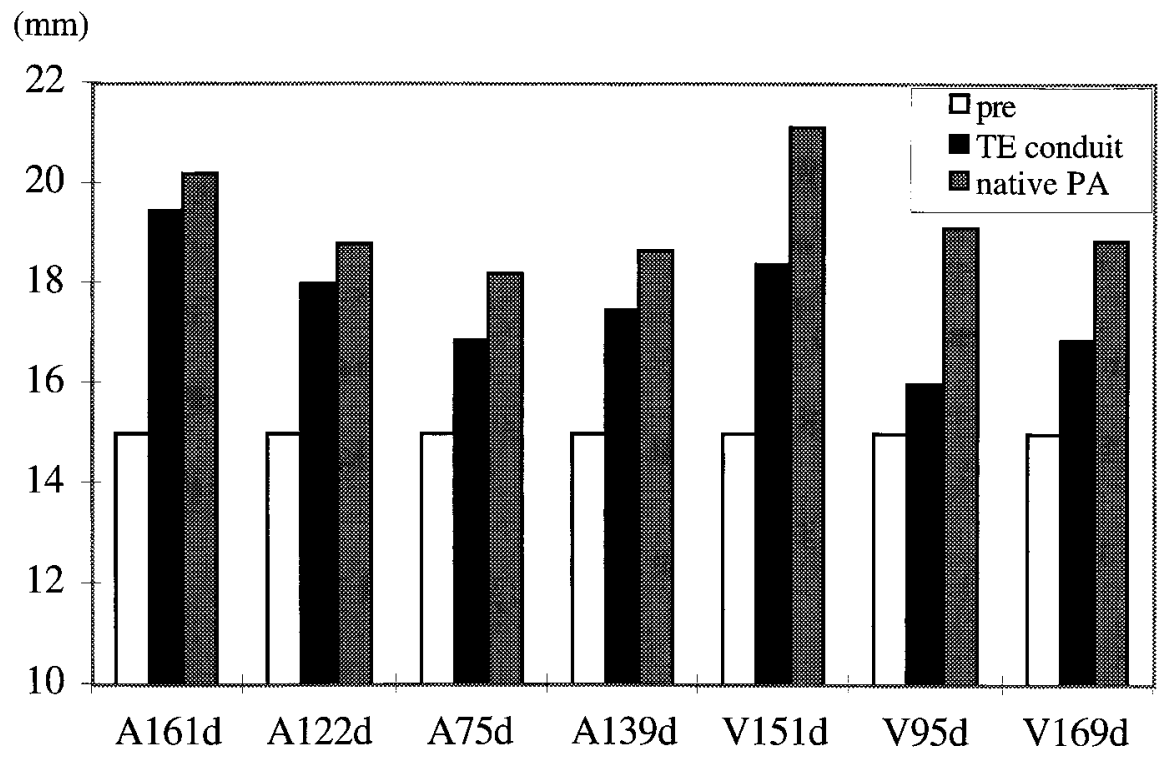

Fig. 4. Changes in diameter of tissue-engineered conduits and native pulmonary artery $(P A)$. $A$, group A; $V$, group $\mathrm{V}$. The numbers represent the days after implantation. 

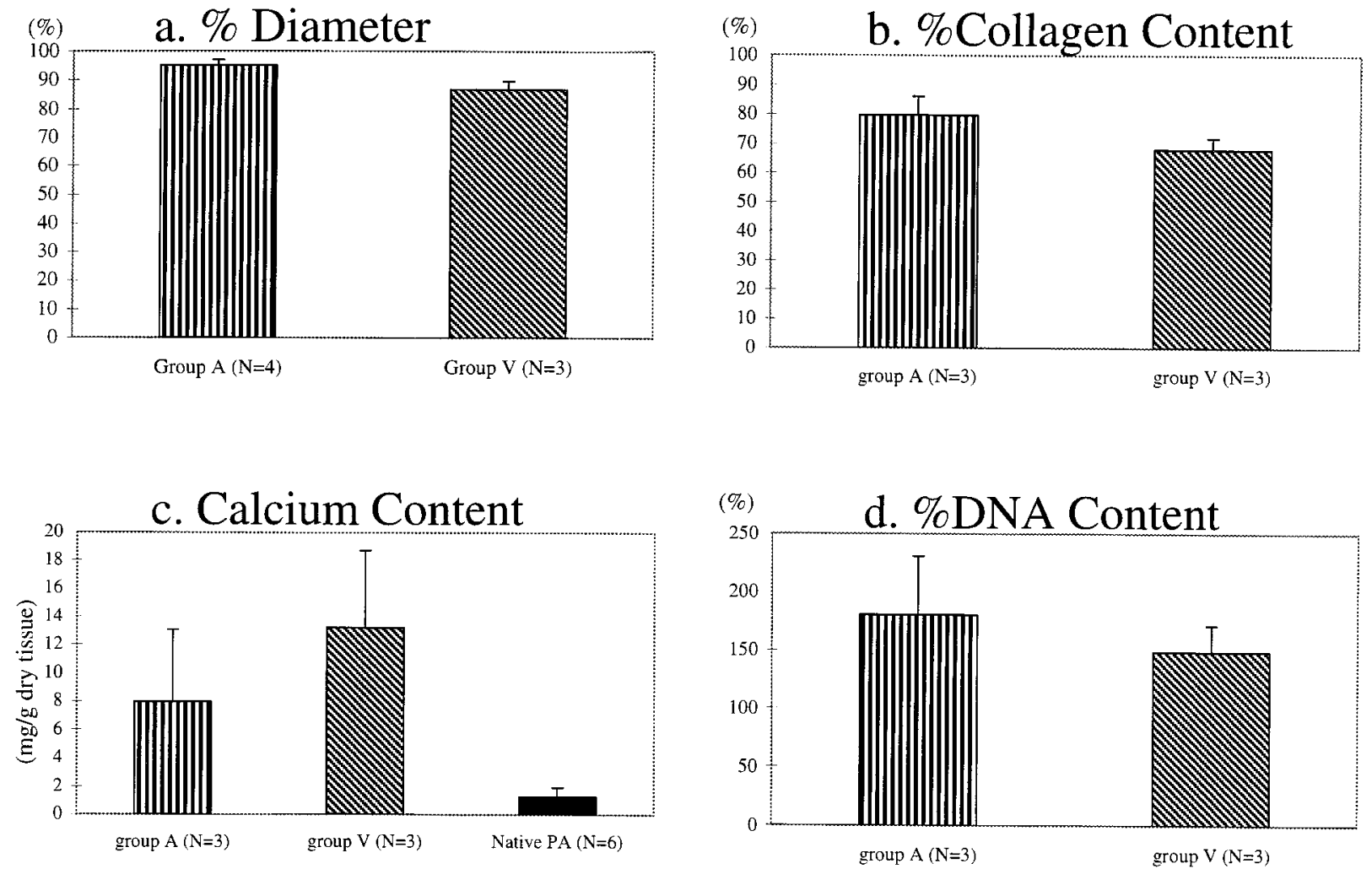

Fig. 5. Comparison of tissue-engineered conduits between groups. a, Diameter of tissue-engineered conduit is expressed as percent of native pulmonary artery. $\mathbf{b}$, Collagen assay is expressed as percent of native pulmonary artery.

$$
\% \text { Collagen }=\frac{\text { Tissue-engineered collagen content } \times 100}{\text { Native pulmonary artery collagen }}
$$

c, Calcium content (ortho-cresolphthalein complex on method) is expressed as milligrams per gram of dry tissue. d, DNA assay.

significant problem that continues to limit its widespread clinical application.

To overcome these shortcomings, efforts have been made to develop an ideal, viable, conduit that should be nonthrombogenic, have growth potential, and require no additional replacement operation. ${ }^{14-17}$

The first attempt to create vascular structure from cellular components was carried out by Weinberg and Bell. ${ }^{18,19}$ They constructed a three-layered blood vessel model in vitro with collagen matrix as a scaffold for endothelial cells, smooth muscle cells, and fibroblasts. However, the collagen matrix was so distensible that it dilated and ruptured at very low pressure $(<10 \mathrm{~mm} \mathrm{Hg})$. Therefore they had to integrate a Dacron mesh onto the outer layers for additional support. This concept of a "tissue-engi- neered blood vessel" has been reported by other investigators, ${ }^{20-23}$ but to our knowledge none have succeeded with in vivo implantation with a completely bioabsorbable polymer scaffold.

We have applied the methods and principles of $\mathrm{TE}$ in an effort to create viable structures to replace diseased or deficient natural structures. Our laboratory has focused on the use of a biodegradable polymer scaffold as a cell delivery system. Many cell types to be used in engineered tissue can be grown in vitro using tissue culture techniques. Once cells are attached to a three-dimensional biodegradable polymer, the resulting tissue construct can be implanted in vivo, where the cells continue to grow and develop a predesigned structure. While the cellular structure and matrix develop, the polymer degrades, 

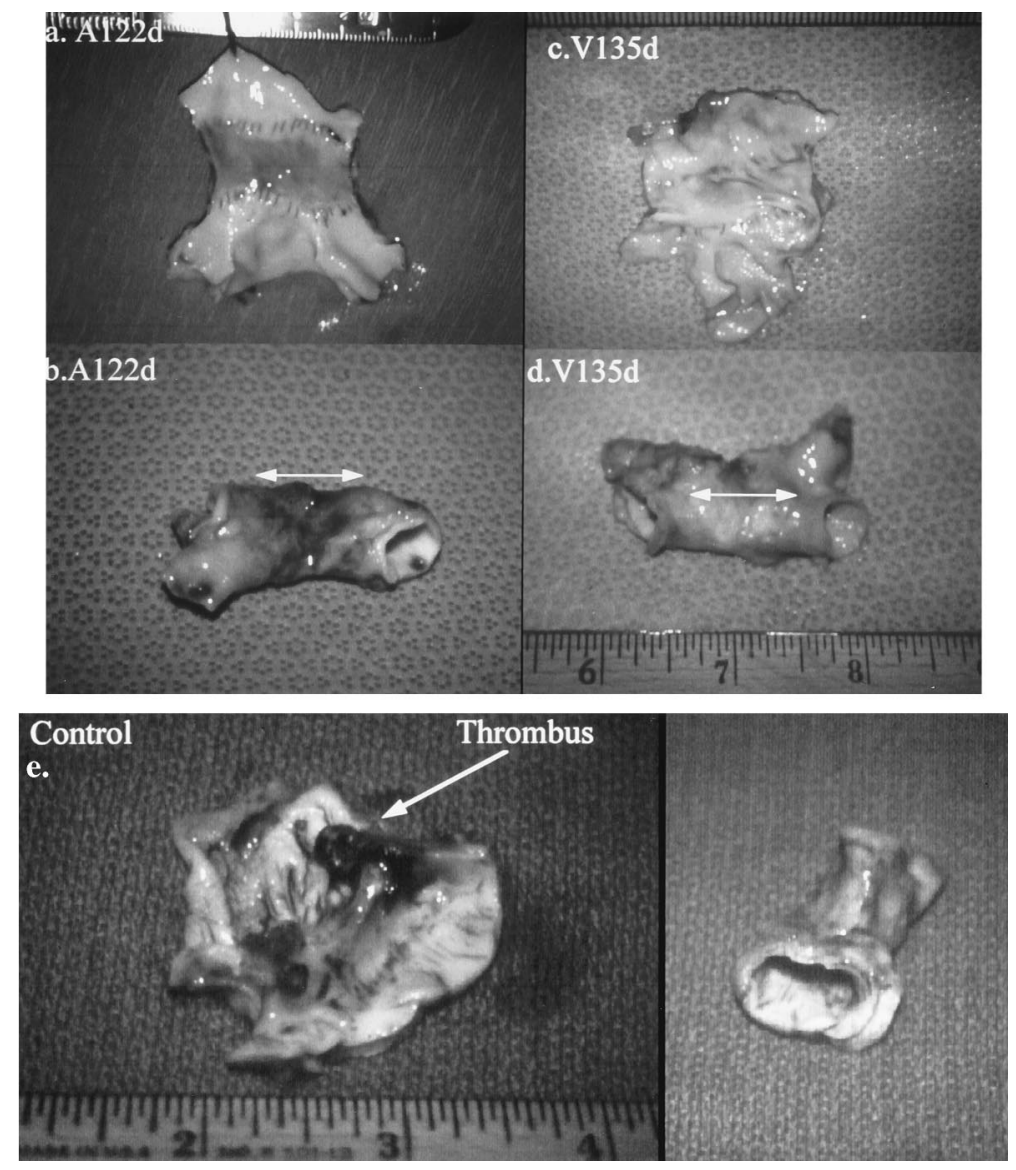

Fig. 6. Gross appearance of tissue-engineered conduit. a and b, Group A, 122 days after implantation. c and d, Group V, 135 days after implantation. e, Control conduit. Note progressive thrombus formation on the luminal surface of the conduit. Diameter of the conduit is also decreased.

ultimately leaving only the engineered tissue without foreign material. The remaining cells and matrix have the potential to remodel and organize into functional tissue that can be used for reconstructive or transplantation operation. ${ }^{24,25}$ This approach of creating tissue from autologous cells offers many potential advantages. It eliminates the problems of rejection and donor organ scarcity. Our results have demonstrated evidence of functional endothelial cells and viable fibroblasts in these implanted conduits. We have previously demonstrated that cells in tissue-engineered valve leaflets have the capacity to generate collagen, elastic fibers, factor VIII, and attained mechanical properties resembling native tissue. ${ }^{3}$ The conduit vessels in this study appear to be viable structures that may have the potential for greater durability because they could use naturally existing mechanisms for repair and remodeling. The problems associated with foreign body reaction and the need for long-term anticoagulation can also be eliminated. Finally, they appear to even possess the potential for growth, which is of unique significance in the pediatric population.

In previous studies replacing one pulmonary valve leaflet in a lamb model, we have shown that the cultured cells seeded in vitro onto the bioabsorbable polymer could maintain their biologic activities in vivo. With cell tracing, we have demonstrated that the in vitro-labeled cells were traced within the matrix even after the complete degradation of the polymer scaffold. By contrast, implanted polymer without cell seeding disappears completely over time, suggesting that the presence of seeded cells was a critical part of the tissue generation process. This finding suggests that in vitro cell seeding is necessary to engineer new tissue. In addition, in the current experiments the control animal that underwent PA replacement using polymer tube without 

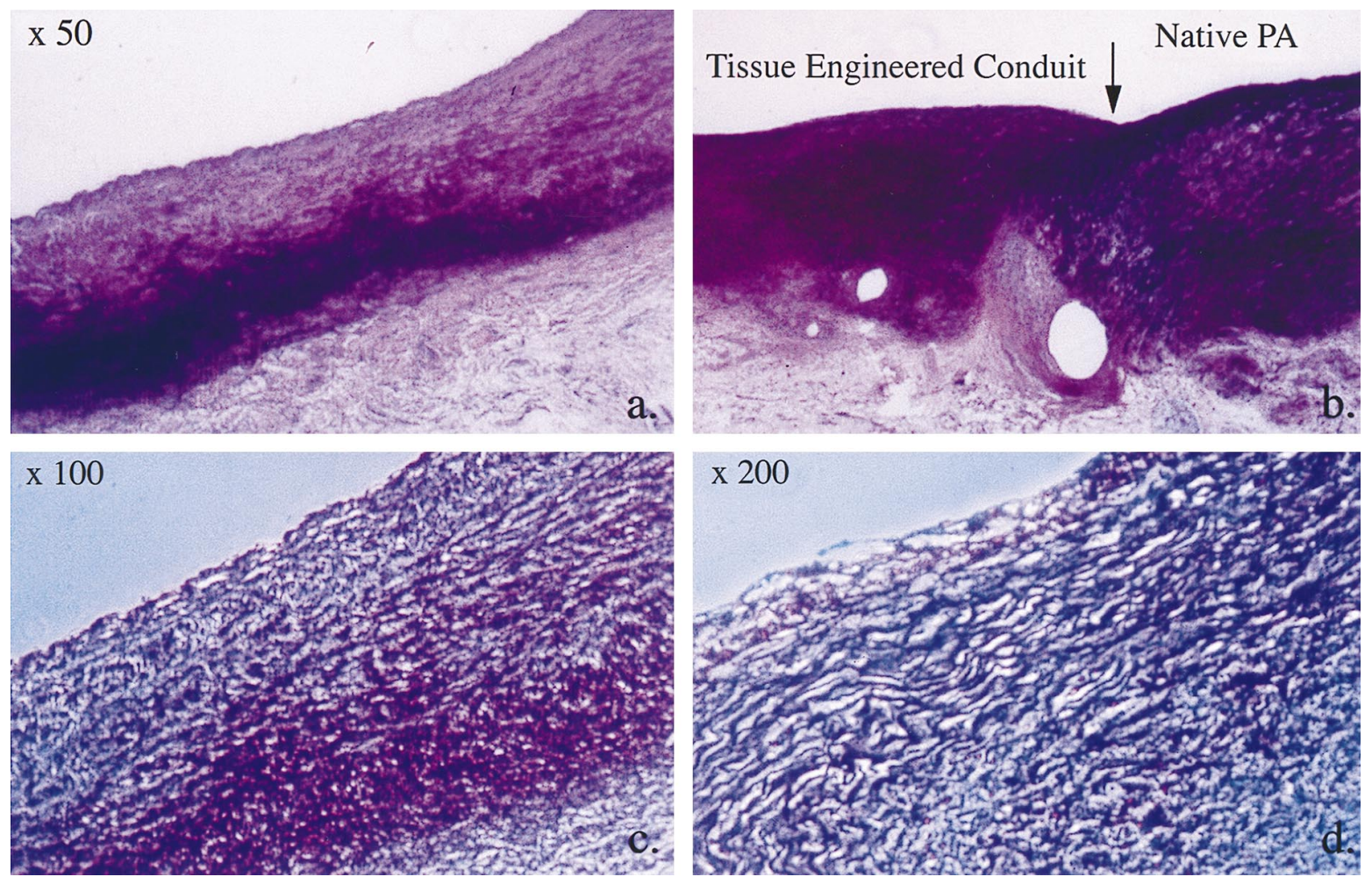

Fig. 7. Miller's elastic staining confirmed the presence of elastic fibers (black staining material) and collagen fibers in the constructed conduit. a, Tissue-engineered conduit after 4 months of implantation in group A (original magnification $\times 50$ ). b, Junction between tissue-engineered conduit and native pulmonary artery $(P A)$ (original magnification $\times 50$ ). c, Tissue-engineered conduit in group $\mathrm{V}$ (original magnification $\times 100$ ). d, Tissue-engineered conduit in group V (original magnification $\times 200$ ).

cells had severe thrombus formation develop, leading to pulmonary stenosis. This finding suggests that cell seeding is also necessary to prevent the formation of thrombus on the luminal surface of conduit. The possibility exists that recipient cell migration from the adjacent native vessel onto the polymer could also contribute to tissue formation, and circulating endothelial cells have also been hypothesized to be important in neoendothelialization after endothelial injury. ${ }^{26}$ These circulating endothelial cells might attach to the luminal surface, and seeded cells might support the endothelial cells to grow quicker. Our results with tissue-engineered valve leaflets and labeled endothelial cells suggests that most of the cells in the tissue-engineered structures are those resulting from in vitro seeding. ${ }^{4}$

Previous studies have also confirmed that the use of allogenic arterial cells or autologous dermal fibroblasts would result in early graft failure, probably because of rejection and tissue contraction, respectively. This study has shown that venous fibro- blasts and endothelial cells have no demonstrable histologic or morphologic differences from arterial wall cells. Whether this is due to the short-term follow-up of this study or to the alterations of cellular phenotypes after in vitro expansion remain to be determined. Although the DNA content studies suggested decreasing cell numbers with time, it is not entirely clear that this represents "maturation" of the tissue in the true sense.

These early results with tissue-engineered pulmonary conduits appears promising, although many issues remain to be addressed. The longer term physiologic and growth characteristics of these implanted constructs clearly require further investigation. Nevertheless, the creation of a conduit from autologous cells that seem to be viable structures is a potentially important breakthrough in this field. Construction of the most physiologic and natural $\mathrm{PA}$, using the principles and methods of TE, has the potential for an important impact in the management of patients with congenital heart disease. 

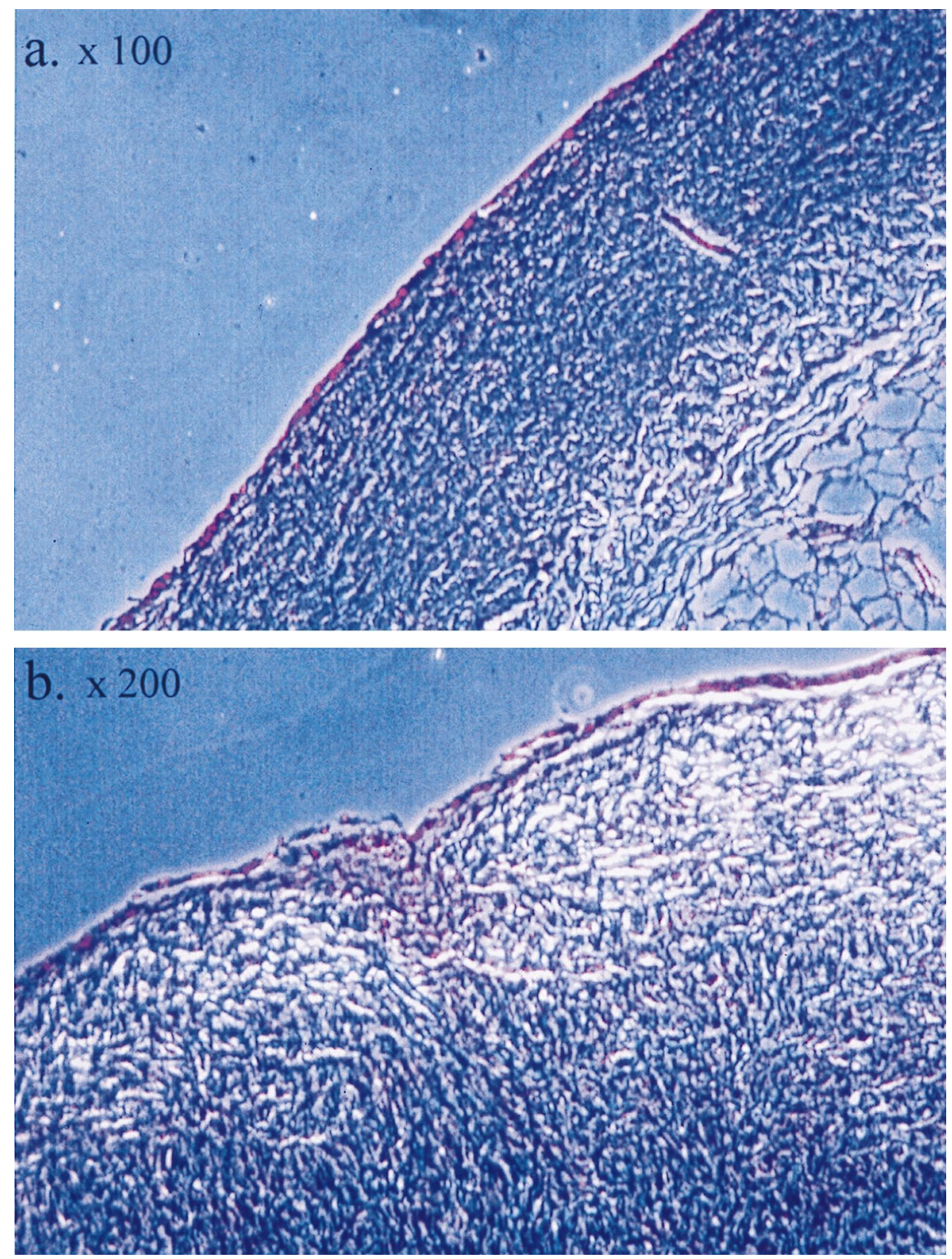

Fig. 8. Positive factor VIII staining (red) from the endothelial cells were identified along the luminal surface of tissue-engineered conduit. a, Group A (original magnification $\times 100$ ). b, Group V (original magnification $\times 200)$.

Several limitations still must be overcome before the clinical application of these tissue-engineered pulmonary arterial conduits will be possible. An ideal conduit suitable for clinical application should have not only growth potential and nonthrombogenicity but it also should have other characteristics such as flexibility, lack of bulkiness, ease of passing sutures, and low porosity. A major limitation of the current biodegradable polymer is its stiffness before in vivo implantation. The optimal duration of in vitro seeding remains to be determined because prolonged incubation will result in the degradation of the bioabsorbable polymer. On the other hand, the composite polymer will remain too stiff and nonpliable for surgical manipulation if implanted prematurely. No visible calcification was observed in any tissue-engineered conduit. More long-term follow-up is necessary to determine whether the increased DNA content represents a transient active cellular metabolism or the ultimate development of 
atherosclerotic calcification. Active experimental research to develop a flexible elastic polymer in this field is currently underway at this institution.

We gratefully acknowledge ChemoSero-Therapeutic Research Institute, Japan, for providing the pasteurized fibrin glue.

\section{REFERENCES}

1. Mayer JE Jr. Uses of homograft conduits for right ventricle to pulmonary connections in the neonatal period. Semin Thorac Cardiovasc Surg 1995;7:130-2.

2. Shinoka T, Breuer CK, Tanel RE, Zund G, Miura T, Ma PX, et al. Tissue engineering heart valves: valve leaflet replacement study in a lamb model. Ann Thorac Surg 1995;60: 5513-6.

3. Shinoka T, Ma PX, Shum-Tim D, Breuer CK, Cusick RA, Zund G, et al. Tissue-engineered heart valves: autologous valve leaflet replacement study in a lamb model. Circulation 1996;94(Suppl):II164-8.

4. Breuer CK, Shinoka T, Tanel RE, Zund G, Mooney DJ, Ma $\mathrm{PX}$, et al. Tissue engineering lamb heart valve leaflets. Biotech Bioeng 1996;50:562-7.

5. Ma PX, Langer R. Degradation structure and properties of fibrous nonwoven poly(glycolic acid) scaffolds for tissue engineering. In: Mikos AG, Leong KW, Radomsky ML, Tamada JA, Yaszemski MJ, editors. Polymers in medicine and pharmacy. Pittsburgh: 1995;394:99-104.

6. Bergman I, Loxley R. Two improved and simplified methods for the spectrophotometric determination of hydroxyproline. Anal Chem 1963;35:1961-5.

7. Labarca C, Paigen K. A simple rapid, and sensitive DNA assay procedure. Anal Biochem 1980;102:344-52.

8. Connerty HV, Briggs AR. Determination of serum calcium by means of orthocresolphthalein complexon. Am J Clin Pathol 1966;45:290-6.

9. Booyse FM, Sedlak BJ, Rafelson M Jr. Culture of arterial endothelial cells: characterization and growth of bovine aortic cells. Thromb Diath Haemorrh 1975;34:825-39.

10. Danielson GK, Downing TP, Schaff HV, Puga FJ, Di Donato RM, Ritter DG. Replacement of obstructed extracardiac conduits with autogenous tissue reconstructions. J Thorac Cardiovasc Surg 1987;93:555-9.

11. Cleveland DC, Williams WG, Razzouk A. Failure of cryopreserved homograft valved conduits in the pulmonary circulation. Circulation 1992;86(Suppl):II150-3.

12. Molina JE, Edwards J, Bianco R, Clack R, Rasmussen T, Moss G, et al. Growth of fresh-frozen pulmonary allograft conduit in growing lambs. Circulation 1989;80(Suppl):I18390 .

13. Kirklin JK, Smith D, Novick W, Naftel DC, Kirklin JW, Pacifico A, et al. Long-term function of cryopreserved aortic homografts. J Thorac Cardiovasc Surg 1993;106:154-66.

14. Sparks $\mathrm{CH}$. Autogenous grafts made to order. Ann Thorac Surg 1969;8:104-7.

15. Herring MB, Gardner AL, Glover JA. A single stage technique for seeding vascular grafts with autologous endothelium. Surgery 1978;84:498-504.

16. Stanley JC, Burkel WE, Ford J, Vinter DW, Kahn RH, Whitehouse WM, et al. Enhanced patency of small-diameter, externally supported Dacron iliofemoral grafts seeded with endothelial cells. Surgery 1982;92:994-1005.

17. Noishiki Y, Tomizawa Y, Yamane Y, Okoshi T, Satoh S, Matsumoto A. Acceleration of neointima formation in vascular prostheses by transplantation of autologous venous tissue fragments. J Thorac Cardiovasc Surg 1993;105:795-804.

18. Weinberg CB, Bell E. A model of an artery constructed from cultured vascular cells and collagen [abstract]. J Cell Biol 1984;99:66a.

19. Weinberg CB, Bell E. A blood vessel model constructed from collagen and cultured vascular cells. Science 1986;231:397400.

20. Ziegler T, Nerem RM. Tissue engineering a blood vessel: regulation of vascular biology by mechanical stresses. J Cell Biochem 1994;56:204-9.

21. L'Heureux N, Germain L, Labbe R, Auger FA. In vitro construction of a human blood vessel from cultured vascular cells: a morphologic study. J Vasc Surg 1993;17:499-509.

22. Williams SK, Jarrell BE. Tissue-engineered vascular grafts. Nat Med 1996;2:32-4

23. Massia SP, Hubbell JA. Tissue engineering in the vascular graft. Cytotechnology 1992;10:189-204.

24. Langer R, Vacanti JP. Tissue engineering. Science 1993;260: 920-6.

25. Vacanti JP. Beyond transplantation. Third Annual Samuel Jason Mixter lecture. Arch Surg 1988;123:545-9.

26. Asahara T, Schatterman G, Sullivan A, Silver M, Isner JM. Blood cell derived endothelial cell precursor can participate in angiogenesis in vivo. Circulation 1996;94(Suppl):1-102.

\section{Discussion}

Dr. John H. Kennedy (Cambridge, United Kingdom). I have only one small question. In presenting a tissue substitute for the native PA, notably lacking in your presentation was the presence or absence of the proteoglycan fraction, the highly negative charged molecules, where presumably early calcification triggered by perhaps galactosidase proteins and osteopontin bring about the clinical problem that we are all trying to approach. I wonder whether the increase in calcium without the evidence of calcification is because the proteoglycan moiety is absent in your experimental model?

Dr. Shinoka. Thank you for your comments. We did not specifically investigate the presence or absence of proteoglycan fraction in this study. Obviously, this is an initial study to test the feasibility of TE of vascular conduits. There are many questions remaining to be answered, especially at the molecular level. At present, the actual meaning of the elevated calcium level in the tissueengineered graft is not yet determined. However, in a previous study using dermal fibroblasts instead of arterial wall cells in valve leaflets demonstrated macroscopic calcification and stenosis. In these dermal fibroblast constructs, calcium content was more than $100 \mathrm{mg} / \mathrm{gm}$ dry tissue. Your point is very well taken, and I believe more long-term studies and more sophisticated molecular analyses will be very important.

Dr. Edward D. Verrier (Seattle, Wash.). I have three questions. Number one, is the evidence of growth anything other than dilatation when the scaffolding absorbs?

Number two, are there smooth muscle cells present? If you use endothelial cells, I would imagine you might get a 
significant proliferation of smooth muscle cells. Is that present?

And the third question is: What are the vascular properties of these endothelial or smooth muscle cells? Does the conduit vasodilate or vasoconstrict? Do you think that it is going to have an intimal hyperplastic response based on its vascular biology? Is any of that known?

Dr. Shinoka. With respect to your first question, it is always difficult to differentiate dilatation versus growth. However, there are several clues that suggest the latter. First, the diameter of tissue-engineered graft increased in proportion to the native PA. Second, the DNA contents that reflected cell numbers were higher than the native PA at 6 months while the diameter was increased. In simple dilatation, one would expect an increase in diameter without increase in cell numbers. Third, at the histologic level, the collagen content and elastic fibers did not resemble those of simple dilatation. Therefore you may call it growth or dilatation. The point is that the tissueengineered graft behaved closely like the adjacent native PA.

Regarding the smooth muscle cells, we did not observe any significant overproliferation in this large vessel study, but that might be related to the low-pressure system at the pulmonary circulation. We did observe this problem in small arterial grafts subjected to systemic arterial pressure. We believe that many cell-to-cell interactions and signals will affect this cellular growth pattern and the formation of intimal hyperplasia. Further investigations are underway to try to improve the current polymer, cell seeding methods, and in vitro preconditioning in an attempt to overcome this challenging problem.

Finally, we did not investigate the vascular properties of these tissue-engineered grafts in this particular study, It is hoped that we will be able to answer this question in the next study in which we are trying to create a tissueengineered aorta.

Dr. Ludwig K. von Segesser (Lausanne, Switzerland). Did you observe tight junctions in your explants?

Dr. Shinoka. I think you raised a very important question with respect to the ultrastructure of these tissueengineered vascular conduits. Unfortunately, we did not look at these specimens at the electron microscopic level.
We hope this study will stimulate more investigators and enthusiasm to test this TE concept at various levels.

And regarding the calcification, we did recognize the increase in the calcium content in our tissue. However, we did some pilot study using abdominal fibroblast instead of the arterial wall cells. In such a case, calcium content was more than $100 \mathrm{ml} / \mathrm{gm}$ tissue. So in this arterial and venous cell origin conduit the calcium accumulation is very trivial. Even though, I think longer follow-up would be necessary to confirm the calcification of our TE conduit.

Dr. Mayer. In response to Dr. Kennedy's question, we simply have not looked at the proteoglycan content to know whether or not that is playing a role in the development of these tissues. You have to understand this was a feasibility sort of study. I think we are encouraged both from this work and the work that we have done with valve leaflets using very similar approaches. There are a lot of hurdles to be jumped here. The polymer is really not very good in its current form. It is very stiff, it is very difficult to work with. When we tried to replace all three leaflets, for instance, in the pulmonary valve, the animal had pulmonary valvular stenosis.

Our colleagues at MIT, Dr. Robert Langer and his group, have now been supplying us with a flexible polymer, which we hope will get over some of those technical problems. We have an enormous amount of work to do. We have to go back and try to understand the science of what is happening in these structures, what genes we are turning on in the endothelial cells and the smooth muscle, and how cells are interacting. We have unresolved questions about whether we should seed the polymer with mixed cell cultures or whether we should serially seed it with myofibroblasts first, followed by endothelial cells second.

We do have experience in trying to make small arterial grafts that Dr. Verrier was alluding to, I think, when he was asking the question about fibrous intimal hyperplasia. In fact, fibrous intimal hyperplasia does occur when you try to use this same kind of approach in a femoral artery graft. I do not want anyone to think that we are going to have something ready to go into patients in the next year. But we think this is exciting work. We continue to be enthusiastic about it. 